\title{
Portable ocular anterior segment imaging system consisting of a lens-style camera connected to a smartphone
}

\section{Przenośny system służący do obrazowania przedniego odcinka oka składający się z bezkorpusowej kamery połączonej ze smartfonem}

\author{
Maciej Czepita ${ }^{凶}$ \\ Pomorski Uniwersytet Medyczny w Szczecinie, II Katedra i Klinika Okulistyki, al. Powstańców Wlkp. 72, 70-111 Szczecin \\ Pomeranian Medical University in Szczecin, II Chair and Clinic of Ophthalmology \\ $\triangle$ maciej@czepita.pl
}

\begin{abstract}
Introduction: We describe a low cost portable ocular anterior segment imaging system consisting of a lens-style camera linked via a wireless connection to a smartphone.

Materials and methods: A Sony DSC-QX10 lens-style digital camera controlled through a wireless connection with an Android OS based smartphone was attached to a standard camera tripod. Slit illumination of the anterior segment of the eye was done through a Heine HSL-150 hand-held slit lamp held close to the camera.
\end{abstract}

Results: Anterior segment ocular images obtained were of good quality even in low light conditions and most importantly not affected by observer induced vibrations by attaching the camera to a tripod.

Conclusions: Our method of ocular anterior segment imaging may be of benefit to eye care specialists when out of the office or when providing care to patients living in communities in the developing world.

Keywords: slit lamp; anterior eye segment; diagnostic imaging; smartphone.

\begin{abstract}
ABSTRAKT
Wstęp: W artykule opisano tani, przenośny system służący do obrazowania przedniego odcinka oka, składający się z bezkorpusowej kamery połączonej bezprzewodowo ze smartfonem. Materiały i metody: Bezkorpusową kamerę cyfrową Sony DSC-QX10, sterowaną bezprzewodowo smartfonem opartym na systemie operacyjnym Android OS, przymocowano do standardowego statywu fotograficznego. Oświetlenie szczelinowe przedniego odcinka oka wykonywano ręczną lampą szczelinową Heine HSL-150 trzymaną w pobliżu kamery.
\end{abstract}

Wyniki: Nawet przy słabym oświetleniu uzyskiwano dobrej jakości obrazy przedniego odcinka oka i, co najważniejsze, dzięki przymocowaniu kamery do statywu fotograficznego nie zauważano wibracji wywołanych przez badającego.

Wnioski: Metoda własna obrazowania przedniego odcinka oka może być stosowana przez specjalistów chorób oczu w trakcie pracy poza gabinetem lub gdy leczą pacjentów żyjących w społeczeństwach rozwijającego się świata.

Słowa kluczowe: lampa szczelinowa; przedni odcinek oka; obrazowanie diagnostyczne; smartfon.

\section{INTRODUCTION}

Anterior segment imaging is routinely performed by ophthalmologists nowadays. A number of office-based and portable handheld systems are available. There have also been various articles published on how to construct special camera adaptors, to slit lamps and attachments for smartphones [1, 2, 3, 4]. Currently, there has been growing interest in developing low cost and miniaturized equipment with the anterior segment and ocular fundus imaging capabilities [5]. Often this equipment requires connecting to a smartphone in order to work.

Lens-style cameras are low cost and lightweight compact digital cameras designed primarily for use with smartphones, which they connect to usually by using WiFi. They are supplied with their own controls and shutter buttons enabling them even to operate remotely from a smartphone.

\section{MATERIALS AND METHODS}

For the purpose of this study, we used an 18.2 megapixel Sony DSC-QX10 lens-style camera (Sony Corporation, Tokyo, Japan) connected through WiFi to a Samsung Android OS based smartphone. A special application - PlayMemories Mobile (Sony Corporation, Tokyo, Japan) supplied by the camera manufacturer was installed onto the smartphone. For anterior segment photography, the camera is attached to a standard camera tripod. The photographer is seated behind the camera. With one hand the photographer holds the portable Heine HSL-150 slit lamp (Heine Optotechnik, Herrsching, Germany) close to the camera and in the other hand the smartphone connected to the camera (Fig. 1). The patient is seated in front of the camera at a distance of around half a meter. The photographer views the live image of the eye on the screen of the smartphone and 


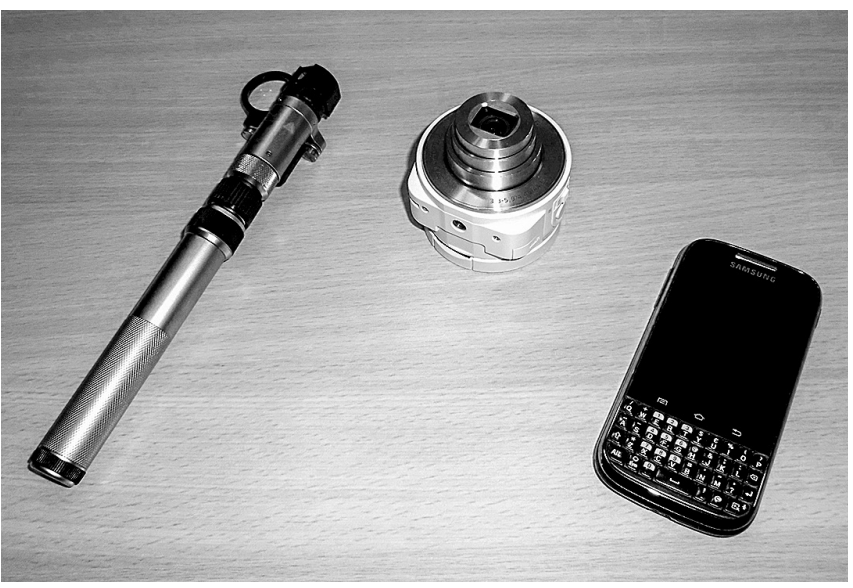

FIGURE 1. Components of our ocular anterior segment imaging system. At left: Heine HSL-150 slit lamp. In the middle: Sony DSC-QX10 lens-styled camera. At right: An Android OS based smartphone

clicks a button on the screen to capture the image. In case the observer needs to have one hand free during the examination (i.e. to lift the upper eyelid) the smartphone can be attached to the back of the camera and the self-timer can be activated. The images are then stored onto a micro-SDHC memory card within the camera. This card can be removed from the camera and inserted to some other device such as a computer for viewing. However, images can also be easily accessed through $\mathrm{WiFi}$ and viewed on the screen of the smartphone by using the supplied PlayMemories Mobile application. They can also be easily stored onto the memory of the smartphone through this application. Further image cropping was done through the Gallery application of the smartphone.

\section{RESULTS}

We captured several anterior segment images in different patients. A representative example of anterior segment imaging with thin slit illumination and background light can be seen in the image of the right eye of a 33-year-old male in Figure 2 and in the image of the left eye of a 58-year-old female in Figure 3. On this picture the pupil was pharmacologically dilated, while in Figure 2 it was not. The crystalline lens is visible in both cases. In Figure 4 a small conjunctival nevus of the right eye in a 30-year-old female can be seen in direct illumination with a wide slit.

\section{DISCUSSION}

To date, a number of portable handheld devices for anterior segment photography have appeared. These devices however usually require holding them with both hands by the observer. Therefore, images can suffer from observer induced vibrations. Our method completely eliminates this problem by placing the camera on a tripod. Another advantage that we observed was good image illumination in the low lighting conditions of our examination dark room. Images can be taken with illumination conditions of only 20 lux. Finally, the low cost of our equipment has to be emphasized. The cost of the Heine HSL150 slit lamp, Sony DSC-QX10 camera with the memory card and camera tripod was 800 USD. However, it is to be noted that images acquired using our method are of lower quality and magnification than those made with conventional tabletop slit lamp systems.

\section{CONCLUSIONS}

Our method of anterior segment imaging can be of use to eye care specialists examining patients when out of the office or when providing care to patients living in communities in the developing world.

\section{REFERENCES}

1. Chan JB, Ho HC, Ngah NF, Hussein E. DIY - Smartphone Slit-Lamp adaptor. J Mob Technol Med 2014;3:16-22.

2. Gokhale NS. Home made adapter for hands-free smart phone slit lamp photography. J Clin Ophthalmol Res 2015;3:160-2.

3. Raju B, Raju N, Akkara JD, Pathengay A. Do it yourself smartphone fundus camera - DIYretCAM. Indian J Ophthalmol 2016;64:663-7.

4. Khatib ZI, Khanna V, Dyaberi R. Smartphone indirect ophthalmoscopy: for screening, evaluation and documentation of the ocular fundus. J Ophthalmic Surg Ocular Pharmacology 2016;1(1):15-20.

5. Shanmugan MP, Mishra DK, Madhukumar R, Ramanjulu R, Reddy SY, Rodrigues $\mathrm{G}$. Fundus imaging with a mobile phone: review of techniques. Indian J Ophthalmol 2014;62:960-2.

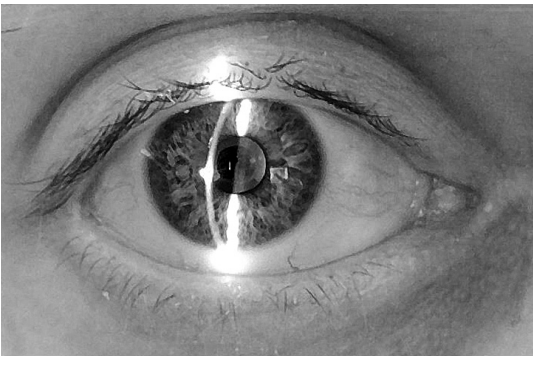

FIGURE 2. The right eye of a 33-year-old male with slit illumination and background light

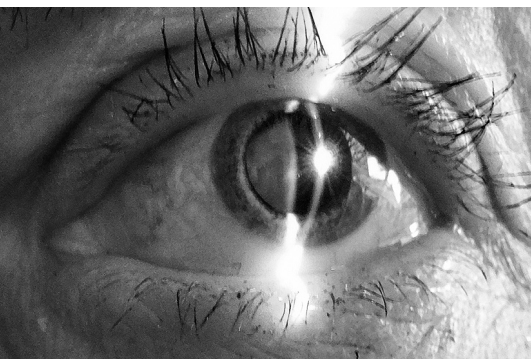

FIGURE 3. The left eye of a 58-year-old female with slit illumination and background light

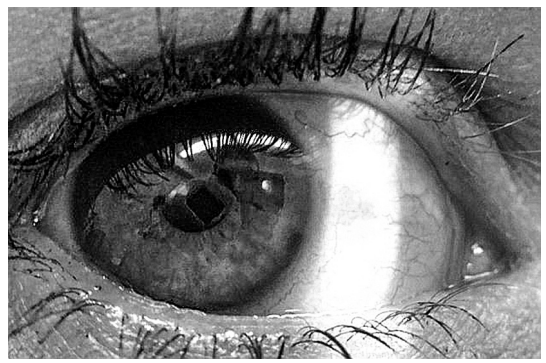

FIGURE 4. Conjunctival nevus of the right eye in a 30 -year-old female 